\title{
SAINTIFIK BERBASIS CONTEXTUAL TEACHING AND LEARNING TERHADAP KEMAMPUAN SAINS PADA PEMBELAJARAN ANAK USIA DINI
}

\author{
Igha Putri Kesuma ${ }^{1} \&$ Parwoto $^{2}$ \\ ${ }^{12}$ Pendidikan Guru Pendidikan Anak Usia Dini, Universitas Negeri Makassar
}

\begin{abstract}
:
The purpose of this study was to determine the effectiveness of a contextual teaching and learning based positive approach to children's science skills at PAUD Al-Wildan Kec. Wonomulyo Kab. Polewali Mandar. The approach used in this research is a quantitative research approach. This type of research is a quasi-experimental design or quasiexperimental. The data collection techniques used were observation, tests, and documentation. The results of calculations using the t-hypothesis test (Separated Varian) obtained t count greater than t table at a significant level and a certain degree of freedom. So it can be concluded that the science ability of the group of children who take the CTLbased scientific approach learning is in the high category, and there is a positive effect of the application of the CTL-based scientific approach on the science skills of children in PAUD Al-Wildan, Wonomulyo, Polewali Mandar.
\end{abstract}

Keywords: CTL-based scientific approach, Science ability.

\begin{abstract}
Abstrak:
Tujuan penelitian ini untuk mengetahui efektivitas pendekatan saitifik berbasis contextual teaching and learning terhadap kemampuan sains anak pada PAUD Al-Wildan Kec. Wonomulyo Kab. Polewali Mandar. Pendekatan yang digunakan dalam penelitian ini adalah pendekatan penelitian kuantitatif. Jenis penelitian yang digunakan adalah quasiexperimental design atau eksperimen semu. Teknik pengumpulan data yang digunakan adalah observasi, tes, dan dokumentasi. Hasil perhitungan dengan menggunakan uji hipotesis-t (Separated Varian) diperoleh $t_{\text {hitung }}$ lebih besar dibanding $t_{\text {tabel }}$ pada taraf signifikan dan derajat kebebasan tertentu. Sehingga dapat disimpulkan bahwa kemampuan sains kelompok anak yang mengikuti pembelajaran pendekatan saintifik berbasis $C T L$ termasuk kategori tinggi, serta terdapat pengaruh positif penerapan pendekatan saintifik berbasis $C T L$ terhadap kemampuan sains anak di PAUD Al-Wildan Kecamatan Wonomulyo Kabupaten Polewali Mandar.
\end{abstract}

Kata Kunci: Pendekatan saintifik berbasis CTL, kemampuan sains. creativecommons.org/licenses/by-nc/4.0/). Received: April 2019, Accepted: Mei 2019, Published: Juni 2019 
16| TEMATIK, Desember 2019, Volume 5, Nomor 1, Halaman 15-21

\section{PENDAHULUAN}

Masa kanak-kanak merupakan periode emas yang hanya terjadi sekali dalam kehidupan manusia. Periode emas atau masa anak usia dini terjadi pada tahun-tahun pertama kehidupan manusia, yaitu sejak lahir hingga usia enam tahun. Pada masa ini pertumbuhan dan perkembangan manusia dalam berbagai aspek berlangsung pesat, utamanya pada perkembangan struktur otak, yakni $80 \%$ dari perkembangan otak orang dewasa secara keseluruhan. Setelah anak berusia enam tahun hingga masa dewasa, perkembangan otaknya tidak lebih dari 20\% (Suyadi, 2011).

Laju pertumbuhan dan perkembangan berbeda pada setiap anak menyebabkan mereka terbentuk menjadi individu unik, dimana setiap anak memiliki potensi yang berbeda-beda. Seorang anak tidak bisa dibandingkan dengan anak yang lain maupun dengan orang dewasa, baik dari pola pikir maupun fisiknya. Anak bukan orang dewasa mini, memiliki dunia sendiri yang harus dipandang dengan sudut pandang mereka karena anak-anak bersifat egosentris, mereka belum bisa memandang masalah dari sudut pandang orang lain. Dunia anak adalah dunia bermain, mereka memiliki rasa ingin tahu yang tinggi, dan suka bereksplorasi dengan benda-benda di sekitarnya karena anak adalah penjelajah ulung.

Anak usia dini juga disebut masa prasekolah, memiliki masa peka dalam perkembangannya, serta terjadi pematangan fungsi fisik dan psikis yang siap menerima berbagai rangsangan dari lingkungan (Sujiono, 2013). Masa ini merupakan masa paling tepat untuk meletakkan dasar pertama dan utama dalam mengembangkan berbagai potensi serta membangun karakter dan kepribadian dalam diri mereka. Untuk mengarahkan anak dalam mengembangkan potensi-potensi yang mereka miliki, diperlukan peran orang dewasa dalam hal ini menyelenggarakan pendidikan. Salah satu upaya yang dilakukan adalah dengan menyelenggarakan pendidikan anak usia dini.

Pendekatan saintifik adalah pendekatan yang merancang kegiatan pembelajaran melalui tahapan-tahapan tertentu agar anak didik berperan aktif dalam proses belajar (Sani, 2015). Tahapan aktivitas belajar dalam pembelajaran pendekatan saintifik tidak harus dilakukan melalui prosedur yang kaku, namun dapat disesuaikan dengan pengetahuan yang hendak dipelajari. Pada suatu kegiatan pembelajaran anak didik dapat melakukan observasi sebelum mengajukan pertanyaan, tapi dalam kegiatan pembelajaran yang lain anak didik juga dapat mengajukan pertanyaan sebelum pengamatan dan melakukan percobaan serta mengumpulkan data.

Menurut Komalasari (2011), Contextual Teaching and Learning (CTL) atau pembelajaran kontekstual merupakan konsep pembelajaran yang membantu pendidik mengaitkan antara materi yang diajarkan dengan kehidupan nyata anak didik. Hal ini memungkinkan anak didik menghubungkan isi materi dengan konteks kehidupan nyata untuk menemukan makna. Sehingga pengetahuan yang diperoleh saat belajar dapat diterapkan dalam kehidupan mereka sebagai anggota keluarga, masyarakat, dan warga negara. Sedangkan menurut Suprijono (2012), pembelajaran kontekstual memusatkan proses pembelajaran pada anak didik agar mereka mengerti makna dan manfaat dari materi yang telah dipelajari. Dalam proses pembelajaran pendidik menciptakan situasi belajar untuk mendorong anak didik berperan aktif dalam menemukan makna dari setiap pengalaman belajar. Sehingga anak didik memiliki pengalaman nyata dan pengetahuan yang bermakna bagi kehidupan mereka.

Menurut Aqib (2013), langkah-langkah penerapan contextual teaching and learning atau pembelajaran kontekstual secara garis besar dapat dilakukan dengan tahapan sebagai berikut; 1) mengembangkan pemikiran bahwa anak akan belajar lebih bermakna jika mengonstruksi pengetahuan dan keterampilan barunya secara mandiri, 2) memberikan kesempatan pada anak didik melakukan pengamatan dan menggunakan keterampilan berpikir agar memahami topik pembelajaran, 3) mengambangkan sifat ingin tahu anak 
didik dengan memberi kesempatan bertanya, 4) menciptakan kelompok belajar, 5) menghadirkan model sebagai contoh dalam kegiatan pembelajaran, 6) melakukan refleksi diakhir pertemuan, dan 7) melakukan penilaian yang sebenarnya dengan berbagai cara.

Piaget (Papalia, Old, and Feldman, 2010) dalam teori perkembangan kognitif mengelompokkan anak usia 2-7 tahun pada tahapan praoperasional. Kemampuan sains anak pada tahapan praoperasional merupakan kemampuan mengamati objek konkrit dengan menggunakan semua indera kemudian merepresantasi menggunakan bahasa, tulisan, atau gambar sebagai tempat melekatkan makna. Kegiatan observasi didorong oleh rasa ingin tahu anak tentang lingkungan sekitar sehingga dapat mengamati perubahanperubahan yang terjadi. Kemudian anak membandingkan, memperkirakan, mengklasifikasikan serta mengomunikasikan hasil pengamatan sebagai sebuah pengetahuan.

Mariyana, Nugraha, dan Rachmawati (2010) menyatakan materi pembelajaran sains untuk anak usia dini mengenalkan konsep sebab-akibat secara langsung atau hands on experience. Pendidik dapat menyediakan bahan-bahan dasar untuk pembentukan konsep sederhana tentang sains agar anak didik dapat melakukan dan mengeksplorasi apapun yang mereka inginkan. Pembelajaran sains anak usia dini berisi materi pengenalan tentang binatang, misalnya binatang yang hidup di air, darat, dan udara. Pendidik juga dapat mengenalkan jenis-jenis tanaman, seperti tanaman obat, buah-buahan, bunga, umbiumbian, dan biji-bijian. Selain itu, pendidik dapat mengenalkan magnet, perlengkapan ukur, seperti skala keseimbangan, jam, termometer, dan alat ukur panjang. Pendahuluan berisi latar belakang penelitian, konteks penelitian, tinjauan literatur utama yang mendasari penelitian, dan tujuan penelitian. Penulis sangat disarankan untuk merujuk ke artikel terbaru yang diterbitkan oleh jurnal terkemuka. Pendahuluan harus disajikan dalam paragraf.

Berdasarkan observasi di PAUD Al-Wildan Kec. Wonomulyo, kegiatan pembelajaran yang dilakukan menggunakan pendekatan konvensional. Pembelajaran dengan pendekatan konvensional menjadikan anak sebagai obyek belajar sehingga mereka hanya berperan sebagai pendengar dan pembelajar pasif (Muchlis, 2007). Anak lebih banyak belajar secara individual dengan menerima, menghafal dan menyelesaikan tugas sesuai materi pelajaran yang diberikan. Sedangkan dalam kurikulum 2013 PAUD, menyatakan bahwa perencanaan kegiatan pembelajaran dilakukan dengan pendekatan dan model pembelajaran yang sesuai dengan kebutuhan serta karakteristik anak yang suka bereksplorasi dengan benda-benda di sekitarnya. Sehingga anak dapat berpartisipasi secara aktif dalam menemukan dan membangun makna dari setiap proses pembelajaran serta dapat memaksimalkan kemampuan berdasarkan STPPA.

Oleh karena itu, dibutuhkan pendekatan dan model pembelajaran yang dapat mendorong anak didik berpikir kritis, analitis, tepat dalam menalar dan mengomunikasikan serta membantu mereka mengaitkan materi yang diperoleh dengan kehidupan nyata untuk menemukan makna dan menerapkannya. Maka dipilih pendekatan saintifik berbasis contextual teaching and learning karena pendekatan saintifik merancang kegiatan pembelajaran sedemikian rupa agar anak didik secara aktif mengonstruksi kompetensi sikap, pengetahuan, dan keterampilan sedangkan pembelajaran kontekstual memusatkan proses pembelajaran pada anak didik agar mereka menemukan makna dan manfaat dari materi yang telah dipelajari lalu menerapkan dalam kehidupan sehari-hari.

\section{METODOLOGI}

Pendekatan yang digunakan dalam penelitian ini adalah pendekatan penelitian kuantitatif, yaitu penelitian dilakukan untuk menganalisis efektivitas pendekatan saintifik berbasis $C T L$ terhadap kemampuan sains anak. Jenis penelitian yang digunakan dalam 
penelitian ini adalah quasi-experimental design atau eksperimen semu. Penggunaan jenis penelitian ini berdasarkan sifat populasi, yakni anak didik yang tidak tetap dan bervariasi. Penelitian ini mengkaji dua variabel, yaitu pendekatan saintifik berbasis contextual teaching and learning sebagai variabel bebas atau yang memengaruhi dan kemampuan sains sebagai variabel terikat atau yang dipengaruhi. Desain penelitian yang di gunakan yaitu nonequivalent control group design dimana pengukuran dilakukan melibatkan dua kelompok, yakni kelompok eksperimen dan kelompok control. Populasi dalam penelitian ini adalah seluruh anak didik PAUD Al-Wildan Kec. Wonomulyo yang berjumlah 64 anak, terdiri dari Kelompok $A, B_{1}$ dan $B_{2}$. Sampel yang digunakan pada penelitian ini adalah sebanyak 20 anak, masing-masing 10 anak sebagai kelompok eksperimen dan 10 anak lainnya sebagai kelompok kontrol. Teknik pengambilan sampel yang digunakan dalam penelitian ini adalah teknik purposive sampling (sampling pertimbangan). Pemilihan teknik ini didasarkan pada tujuan penelitian, yakni untuk mengetahui kemampuan sains anak.

Pada tahap perencanaan peneliti menentukan jumlah sampel dan merumuskan instrumen yang berisi item-item berupa tes kemampuan sains untuk melakukan penilaian pada anak. Instrumen yang dibuat divalidasi terlebih dahulu oleh ahli. Butir-butir yang valid tersebut digunakan untuk mengukur kemampuan sains anak. Pemberian pretest dilakukan pada tahap observasi awal dengan menilai kemampuan sains anak pada kelompok eksperimen dan kelompok kontrol sebelum menerapkan pendekatan saintifik berbasis $C T L$ sesuai item tes yang telah dibuat.

Pemberian perlakuan berupa kegiatan pembelajaran sains yang menggunakan pendekatan saintifik berbasis contextual teaching and learning pada kelompok eksperimen dan pembelajaran sains dengan pendekatan konvensional pada kelompok kontrol. Pemberian posttest dilakukan pada kegiatan observasi akhir. Pada tahap ini, peneliti memberi penilaian terhadap kemampuan sains anak setelah menerapkan pendekatan saintifik berbasis $C T L$ pada kelompok eksperimen dan pendekatan konvensional pada kelompok kontrol. Penilaian dilakukan berdasarkan item tes yang sama saat tahap pretest. Tahapan ini bertujuan untuk mengetahui kemampuan sains anak setelah diterapkan pendekatan saintifik berbasis $C T L$.

Analisis hasil merupakan kegiatan membandingkan hasil pretest dan posttest untuk mengetahui perubahan yang terjadi pada kemampuan sains anak. Analisis hasil juga dilakukan untuk mengetahui efektifitas pendekatan saintifik berbasis CTL terhadap kemampuan sains anak. Analisis hasil dari penelitian dilaksanakan sesuai dengan metode penelitian yang digunakan.

Data yang diperoleh sebelum dan setelah penggunaan pendekatan saintifik berbasis CTL dianalisis menggunakan analisis deskriptif dan analisis statistik inferensial. Analisis statistik deskriptif dimaksudkan untuk menggambarkan kemampuan sains anak didik yang menggunakan pendekatan saintifik berbasis CTL dan yang menggunakan pendekatan konvensional dengan melihat skor hasil tes. Analisis statistik inferensial dimaksudkan untuk menguji hipotesis penelitian mengenai ada tidaknya pengaruh pendekatan dan model pembelajaran yang digunakan terhadap kemampuan sains anak._Uji normalitas dilakukan untuk mengetahui apakah data yang diperoleh berasal dari populasi yang terdistribusi normal atau tidak. 


\section{HASIL DAN PEMBAHASAN}

Pada pretest, kemampuan sains kelompok anak yang akan mengikuti pembelajaran dengan pendekatan saintifik berbasis CTL memiliki skor maksimum 18 dan skor minimun 12 , dengan rata-rata 14,8 , varian 3,289, dan simpangan baku 1,814. Kemampuan sains anak yang akan mengikuti pembelajaran dengan pendekatan saintifik berbasis CTL pada interval 18-18 terdapat 1 responden dengan persentase 10\%, interval 16-17 terdapat 3 responden dengan persentase 30\%, interval 14-15 terdapat 3 responden dengan persentase 30\%, dan interval 12-13 terdapat 3 responden dengan persentase 30\%. Kemampuan sains kelompok anak yang akan mengikuti pembelajaran konvensional memiliki skor maksimum 18 dan skor minimun adalah 12, dengan rata-rata 15,1, varian 4,767, dan simpangan baku 2,183. kemampuan sains anak yang akan mengikuti pembelajaran konvensional pada interval 1819 terdapat 2 responden dengan persentase 20\%, interval 16-17 terdapat 3 responden dengan persentase $30 \%$, interval $14-15$ terdapat 2 responden dengan persentase $20 \%$, dan interval 12-13 terdapat 3 responden dengan persentase $30 \%$.

Pada posttest kemampuan sains kelompok anak yang mengikuti pembelajaran dengan pendekatan saintifik berbasis CTL memiliki skor maksimum 20 dan skor minimun 14, dengan rata-rata 17,9, varians 3,433, dan simpangan baku 1,853. kemampuan sains anak yang mengikuti pembelajaran dengan pendekatan saintifik berbasis CTL pada interval 20-21 terdapat 2 responden dengan persentase 20\%, interval 18-19 terdapat 5 responden dengan persentase 50\%, interval 16-17 terdapat 2 responden dengan persentase $20 \%$, dan interval 14-15 terdapat 1 responden dengan persentase 10\%. Kemampuan sains kelompok anak yang mengikuti pembelajaran konvensional memiliki skor maksimum 19 dan skor minimun adalah 13, dengan rata-rata 15,9, varians 3,211, dan simpangan baku 1,792. Kemampuan sains anak yang mengikuti pembelajaran konvensional pada interval 19-20 terdapat 1 responden dengan persentase 10\%, interval 17-18 terdapat 2 responden dengan persentase 20\%, interval 15-16 terdapat 5 responden dengan persentase $50 \%$, dan interval 13-14 terdapat 2 responden dengan persentase $20 \%$.

Uji normalitas dalam penelitian ini menggunakan uji normalitas Liliefors yang dilakukan terhadap dua kelompok data yaitu kemampuan sains kelompok anak yang mengikuti pembelajaran dengan pendekatan saintifik berbasis CTL dan kemampuan sains kelompok anak yang mengikuti pembelajaran konvensional. $L_{\text {hitung }}(0,129)$ pada kelompok pendekatan saintifik berbasis CTL dan kelompok Konvensional lebih kecil dibandingkan $L_{\text {tabel }}(0,258)$, sehingga dapat disimpulkan bahwa sampel penelitian berasal dari populasi yang berdistribusi normal.

Uji homogenitas pada dua kelompok dilakukan melalui uji F yakni menghitung Fratio antara varian terbesar dengan varian terkecil dari kelompok yang diuji, kemudian di bandingkan dengan harga $F_{\text {tabel }}\left(F_{t}\right)$ pada taraf signifikansi 0,05. Berdasarkan hasil perhitungan sebagaimana pada lampiran diperoleh hasil $F_{\text {hitung }}=1,069<F_{\text {tabel }}=$ 3,18 sehingga dapat disimpulkan bahwa skor kemampuan sains kedua kelompok berasal dari populasi yang mempunyai varians yang homogen. Dengan demikian uji statistik inferensial (uji-t) dapat di lanjutkan untuk pengujian hipotesis.

Berdasarkan hasil perhitungan uji-t (Separated Varian) seperti yang terdapat pada lampiran, diperoleh $t_{\text {hitung }}=2,453$ dengan harga $t_{\text {tabel }}=1,734$ dan harga $\mathrm{dk}=18 \mathrm{dan}$ 
taraf signifikansi $\alpha=0,05$. Sehingga jika dibandingkan harga $t_{\text {hitung }}=2,453>$ harga $t_{\text {tabel }}=1,734$. Data ini menunjukkan adanya perbedaan signifikan antara dua kelompok yang diuji. Data perbedaan ini selanjutnya diuji dengan membandingkan rata-rata kedua kelompok perlakuan. Pada kelompok eksperimen rata-ratanya adalah 17,90 sedangkan pada kelompok kontrol rata-ratanya adalah 15,90 , sehingga jika di bandingkan rata-rata dua kelompok tersebut 17,90>15,90.

\section{KESIMPULAN}

Berdasarkan hasil analisis dan uji statistik pada pembahasan sebelumnya, maka dapat ditarik kesimpulan bahwa pendekatan saintifik berbasis contextual teaching and learning efektif meningkatkan kemampuan sains anak. Kemampuan sains kelompok anak yang mengikuti pembelajaran pendekatan saintifik berbasis contextual teaching and learning termasuk kategori tinggi, sedangkan kemampuan sains kelompok anak yang mengikuti pembelajaran konvensional termasuk kategori sedang. Terdapat pengaruh positif penerapan pendekatan saintifik berbasis contextual teaching and learning terhadap kemampuan sains anak di PAUD Al-Wildan Kec. Wonomulyo Kab. Polewali Mandar.

\section{DAFTAR PUSTAKA}

Aqib, Zainal. (2013). Model-model, Media, dan Strategi Pembelajaran Kontekstual. Bandung: Yrama Widya.

Herman, H., \& Rusmayadi, R. (2018). The Effect Of Learning Model "Plan Do Review” On Science Capability Of Children In Kindergarten. Journal Of Advanced Research (IJAR), 6(12), 984-993.

Jumiatin, D. (2015). Pengaruh Pembelajaran Contextual Teaching \& Learning (CTL) Terhadap Keterampilan Sosial Anak Usia Dini. Tunas Siliwangi: Jurnal Program Studi Pendidikan Guru PAUD STKIP Siliwangi Bandung, 1(1), 73-81.

Kementrian Pendidikan dan Kebudayaan. (2015). Kurikulum 2013 Pendidikan Anak Usia Dini. Peraturan Menteri Pendidikan dan Kebudayaan Republik Indonesia Nomor 137 Tahun 2014. Dirjen PAUDNI. Jakarta. (online). http://paud.kemdikbud.go.id/wp-content/uploads/2016/04/Permendikbud137-tahu-2014.pdf.

Komalasari, Kokom. (2011). Pembelajaran Kontekstual. Bandung: Refika Aditama.

Mariyana, Rita, Nugraha, Ali, dan Rachmawati, Yeni. (2010). Pengelolaan Lingkungan Belajar. Jakarta: Kencana.

Muchlis, Masnur. 2007. KTSP Pembelajaran Berbasis Kompetensi dan Kontekstual. Malang: Bumi Aksara

Papalia, Diane E., Old, Sally Wendkos., and Feldman, Ruth Duskin. (2010). Human Development (Psikologi Perkembangan). Diterjemahkan oleh A.K. Anwar. Jakarta: Kencana. 
Sani, Ridwan Abdullah. (2015). Pembelajaran Saintifik untuk Implementasi Kurikulum 2013. Jakarta: Bumi Aksara.

Sugiyono. (2013). Metode Penelitian Pendidikan.Bandung: Alfabeta.

Sujiono, Yuliani Nurani. (2013). Konsep Dasar Pendidikan Anak Usia Dini. Jakarta: Indeks.

Suprijono, Agus. (2012). Cooperative Learning. Yogyakarta: Pustaka pelajar.

Suyadi. (2011). Manajemen PAUD. Yogyakarta: Pustaka Pelajar.

Syamsuardi, S. (2015). Oriented Learning Environment In The Context Of Eraly Childhood Education. Proceeding; International Confrerence for better life 2015. 